\title{
Carbon exchange rates in grazed and ungrazed pastures of Wyoming
}

\author{
DANIEL R. LECAIN, JACK A. MORGAN, GERALD E. SCHUMAN, JEAN D. REEDER, AND RICHARD H. HART
}

Authors are plant physiologists, USDA-ARS, Crops Research Laboratory, Fort Collins, Colo; soil scientist, USDA-ARS High Plains Grasslands Research Station, Cheyenne Wyo.; soil scientist, USDA-ARS Crops Research Laboratory, Fort Collins, Colo; and rangeland scientist, USDA-ARS High Plains Grasslands Research Station, Cheyenne Wyo.

\begin{abstract}
The influence of cattle grazing on carbon cycling in the mixed grass prairie was investigated by measuring the $\mathrm{CO}_{2}$ exchange rate in pastures with a 13 year history of heavy or light grazing and an ungrazed exclosure at the High Plains Grasslands Research Station near Cheyenne, Wyo. In 1995, 1996 and 1997 a closed system chamber, which covered $1 \mathrm{~m}^{2}$ of ground, was used every 3 weeks from April to October to measure midday $\mathrm{CO}_{2}$ exchange rate. Green vegetation index (similar to leaf area index), soil respiration rate, species composition, soil water content, soil temperature, and air temperature were also measured to relate to $\mathrm{CO}_{2}$ exchange rates of the 3 grazing treatments. Treatment differences varied among years, but overall early season (mid April to mid June) $\mathrm{CO}_{2}$ exchange rates in the grazed pastures were higher (up to $2.5 \mathrm{X}$ ) than in the exclosure. Higher early season $\mathrm{CO}_{2}$ exchange rates were associated with earlier spring green-up in grazed pastures, measured as higher green vegetation index. As the growing season progressed, green vegetation index increased in all pastures, but more so in the ungrazed exclosure, resulting in occasionally higher (up to $2 \mathrm{X}$ ) $\mathrm{CO}_{2}$ exchange rate compared with grazed pastures late in the season. Seasonal treatment differences were not associated with soil temperature, soil respiration rate, or air temperature, nor was there a substantial change in species composition due to grazing. We hypothesize that early spring green-up and higher early season $\mathrm{CO}_{2}$ exchange rate in grazed pastures may be due to better light penetration and a warmer microclimate near the soil surface because of less litter and standing dead compared to the ungrazed pastures. When all the measurements were averaged over the entire season, there was no difference in $\mathrm{CO}_{2}$ exchange rate between heavily grazed, lightly grazed and ungrazed pastures in this ecosystem.
\end{abstract}

Key Words: Grazing, productivity, photosynthesis, soil respiration, species composition.

Domestic livestock grazing on rangelands has received much attention recently, as there is often disagreement on the impacts of grazing on ecosystem sustainability. The challenge is manag-

The authors thank Barry Weaver and Dean Ackerman for chamber design and construction, and for assistance with the $\mathrm{CO} 2$ exchange rate measurements, and Pamela Freeman and Stanley Clapp for doing the point quadrat measurements and collecting the climate data. We also thank D.G. Milchunas and H.W. Hunt for excellent and timely reviews.

Manuscript accepted 17 Jul. 1999.

\section{Resumen}

En la Estación Experimental High Plains, cercana a Chayenne, Wyo., se investigo la influencia del apacentamiento de ganado en el reciclaje de carbón en pastizales mixtos. La determinación se efectuó mediante la medición de la tasa intercambio de $\mathrm{CO}_{2}$ en potreros con un historial de 13 años de apacentamiento fuerte o ligero y en potreros excluidos al apacentamiento. Durante el período de Abril a Octubre de 1995, 1996 y 1997 se utilizó un sistema de cámara cerrada (el cual cubría un $1 \mathrm{~m}^{2}$ ) a intervalos de 3 semanas para medir la tasa de intercambio de $\mathrm{CO}_{2}$ al mediodía. También se midieron el índice de vegetación verde (similar al índice de área foliar), la tasa de respiración del suelo, la composición botánica, el contenido de agua del suelo y la temperatura del suelo y aire para relacionarlos con las tasas de intercambio de $\mathrm{CO}_{2}$ de los 3 tratamientos de apacentamiento. Las diferencias entre tratamientos difirieron entre años, pero en general a inicios de la estación (Abril a Junio) las tasas de intercambio de $\mathrm{CO}_{2}$ de los potreros apacentados fueron mayores (hasta 2.5 veces) que las tasas de los potreros excluidos. Las altas tasas de intercambio de $\mathrm{CO}_{2}$ de inicios de estación se asociaron con altos índices de vegetación verde. Conforme la estación de crecimiento avanzó, el índice de vegetación verde aumento en todos los potreros, pero este incremento fue mayor en los potreros sin apacentamiento resultando en tasas de intercambio de $\mathrm{CO}_{2}$ ocasionalmente altas (hasta 2 veces) en comparación con los potreros apacentados a fines de la estación. Las diferencias estacionales de los tratamientos no se asociaron con la temperatura el suelo, la tasa de respiración del suelo o la temperatura del aire, ni tampoco hubo un cambio substancial en la composición de especies vegetales debido al apacentamiento. Nosotros hipotetizamos que el rebrote temprano de primavera y las tasas altas de intercambio de $\mathrm{CO}_{2}$ a inicios de estación de los potreros apacentados puede deberse a una mejor penetración de la luz y a un microclíma más cálido cerca de la superficie del suelo, esto porque hay menos mantillo y vegetación muerta en pie en comparación con los potreros sin apacentar. Cuando todas las mediciones se promediaron en toda la estación completa no hubo diferencias en la tasa de intercambio de $\mathrm{CO}_{2}$ entre los potreros con apacentamiento fuerte, ligero $\mathrm{y}$ sin apacentamiento.

ing these important lands to provide food and products for society, while protecting this natural resource base. As human population increases, so do the demands on rangelands, making it even more important to understand the effects of management strategies on rangelands. 
Many of the world's rangelands have historically been grazed by large mammals, and there is convincing evidence that grasses co-evolved with grazers (Stebbins 1981). As many as 20 million bison existed on the Great Plains of North America before European settlement (Shaw 1995). Therefore, grazing by large mammals is the natural condition of the Great Plains (Milchunas et al. 1988).

The effect of grazing on primary productivity and the carbon cycle are important factors in the long-term sustainability of these ecosystems. However, the information of how animal grazing impacts primary productivity and carbon cycling is limited and inconsistent. For instance, depending on the particular study and rangeland investigated, one can find examples of negative, neutral or positive effects of grazing on above-ground net primary productivity (Milchunas and Lauenroth 1993, Sims and Singh 1978b). McNaughton (1979) maintains that an optimal level of grazing will maximize annual net primary productivity in most rangeland ecosystems, so presumably most of the negative effects of grazing may be examples of over-grazing for a particular ecosystem. Bremer et al. (1998) reported that grazing reduced annual soil respiration by up to $18 \%$ in the tallgrass prairie, indicating that grazing may have a large effect on the carbon cycle of this ecosystem.

Over time, soils will integrate long-term above and below-ground ecosystem processes (Manley et al. 1995, Berg et al 1997). Therefore, soil carbon can be a good relative indicator of the effect of grazing on many aspects of the carbon cycle. However, as with plant productivity, there are reports that grazing increases (Smoliak et al. 1972, Ruess and McNaughton 1987, Schuman et al. 1999), decreases (Bauer et al. 1987, Dormaar and Willms 1998) or does not affect soil carbon (Berg et al. 1997, Milchunas and Lauenroth 1993). Changes in species composition and accompanying changes in rooting patterns resulting from grazing can sometimes explain changes in soil carbon (Smoliak et al. 1972).

An important topic that has not been addressed in the evaluation of how grazing impacts rangeland primary productivity is the photosynthetic response of plant communities to grazing. Many studies have investigated the influence of grazing or simulated grazing on the photosynthesis of individual plants or leaves (Wallace 1990, Painter and Detling 1981). Clipping increases tillering in some grass species and typically stimulates photosynthesis in remaining leaves (Painter and Detling 1981, Detling et al. 1979). However, it is difficult to extrapolate results from single plant or leaf studies to the community level, where species interactions and competition may have a greater impact. Morgan and Brown (1983) reported a positive relation between leaf area index and canopy photosynthesis in mowed Bermudagrass swards. However, there have been few reports of photosynthesis measured on an actively grazed native plant community (McNaughton et al. 1996).

In the mixed grass prairie of southeastern Wyoming, Manley et al. (1995) and Schuman et al. (1999) measured soil carbon of pastures grazed for 12 years vs. ungrazed exclosures. They found greater soil carbon in the upper $30 \mathrm{~cm}$ of soil of grazed pastures compared with ungrazed pastures. Although minor changes in species composition resulted from grazing, this did not help explain the differences in soil carbon.

As a first step towards a more systems oriented approach to understanding the effects of cattle grazing on the carbon cycle in the mixed grass prairie, we investigated how grazing treatments of the same pastures examined by Manley et al. (1995) affected plant community photosynthesis. We hypothesized that the result of grazing on plant community $\mathrm{CO}_{2}$ exchange rate would depend on how grazing affected the photosynthetic surface area of the canopy. We expected that treatment differences in $\mathrm{CO}_{2}$ exchange rate could be explained by corresponding differences in green vegetative surface area of the pasture.

\section{Materials and Methods}

The study site is near Cheyenne Wyo., USA, at the USDA-ARS High Plains Grasslands Research Station (lat. $41^{\circ} 11^{\prime}$ $\mathrm{N}$, long. $104^{\circ} 54^{\prime} \mathrm{W}$ ). The region is a northern mixed-grass prairie with elevations averaging $1,930 \mathrm{~m}$, mean annual precipitation averaging $38.4 \mathrm{~cm}$ and an average of 127 frost free days. Mean air temperatures are $17.5^{\circ} \mathrm{C}$ in summer and $-2.5^{\circ} \mathrm{C}$ in winter, with maximum July temperatures averaging $27^{\circ} \mathrm{C}$. The major cool-season grasses are western wheatgrass (Pascopyrum smithii (Rydb.) A. Love) and needle-and-thread grass (Stipa comata Trin and Rupr.), and the major warm season grass is blue grama (Bouteoloua gracilis (H.B.K.) Lag. Ex
Steud.). The soils are a mixed, mesic, Aridic Argiustolls with the soil series being an Ascalon sandy loam (Schuman et al. 1999).

The study was conducted on pastures grazed since 1982 at a continuous seasonlong (early June to mid-October) light stocking rate (21.6 steer-days $\left.\mathrm{ha}^{-1}\right)$, continuous season-long heavy stocking rate (62.7 steer-days ha $^{-1}$ ) and an ungrazed, 0.5 ha exclosure. The continuous heavy and continuous light stocking rate amounted to about $50 \%$ and $10 \%$ utilization of the annual production. The heavily and lightly grazed pastures share a fence and the exclosure is in the continuous light pasture. Before the initiation of these grazing treatments, the site had not been grazed by domestic livestock for 40 years (for more detail see Hart et al. 1988). The high labor requirements to perform these measurements permitted only 1 pasture of each grazing treatment being sampled to evaluate $\mathrm{CO}_{2}$ exchange rates. Initial soil sampling at the start of grazing trials showed that these pastures had the same soil type, thereby reducing experimental variability. The plant communities within each pasture were quite homogenous.

Metal, angle-iron frames that enclose 1 $\mathrm{m}^{2}$ of ground were driven into the soil along a transect established in 1982. The frames were level with the soil surface and had no apparent effect on cattle activity. Five frames per pasture (pseudo-replications), spaced $5 \mathrm{~m}$ apart, were installed along the transect for a total of 15. Canopy $\mathrm{CO}_{2}$ exchange rate was measured with a 40 (height) x $100 \times 100 \mathrm{~cm}$ 'Lexan' (Regal Plastics, Littleton, Colo. ${ }^{1}$ ) chamber, which had a closed-cell foam gasket on the base, which formed a seal with the metal frames. Air in the chamber was circulated by small fans, and a sample was pumped to a portable infrared gas analyzer (Analytical Development Co. model LCA-2, Hoddesdon, UK). The $\mathrm{CO}_{2}$ exchange rate is then estimated from the rate of $\mathrm{CO}_{2}$ depletion within the chamber. Measurements were performed rapidly (about 2 minutes) to minimize changes to the microclimate caused by the chamber (Angell and Svejcar 1999). $\mathrm{CO}_{2}$ exchange rate measurements were performed from about 1000 to 1300 hours (mountain standard time) approximately every 3 weeks during the growing seasons of 1995, 1996 and 1997. Diurnal measurements made during 1995 showed that maximum daily $\mathrm{CO}_{2}$ exchange rate

\footnotetext{
${ }^{1}$ Mention of a trademark or manufacturer by the USDA does not imply its approval to the exclusion of other products or manufacturers that may also be suitable.
} 
occurred at this time of day (also see Detling et al. 1978). The sequence of measurement among pastures was varied each date to reduce differences related to time of day. In 1995, we measured CO2 exchange rate on only 6 dates due to inclement weather during the spring (measurement requires cloud free conditions).

On each measurement date the point frame method was used to determine the relative photosynthetic surface area and species composition within each sample frame (Warren-Wilson 1963). Though the point frame method has limitations when used to determine leaf area index and for detecting less abundant species (Hazlett 1992, D. G. Milchunas pers. comm.) we considered it the best method of nondestructively determining photosynthetic surface area and species composition on plots which were repeatedly sampled. Green leaves, stems, and sheaths were recorded by the point frame since all 3 are significant contributors to photosynthesis (Caldwell et al. 1981). Total number of green tissue "hits" as 100 points were passed through the canopy of each $1 \mathrm{~m}^{2}$ plot (500 points per pasture) were recorded to get a "green vegetation index". The hits were identified by species for determination of community composition. Soil water content was estimated from 0-30 $\mathrm{cm}$ soil cores and converted to a volumetric basis by multiplying by the soil bulk density (Schuman et al. 1999). Air temperature and light intensity (Analytical Development Co. model PLC(N), Hoddesdon, UK) were also determined at the time of each $\mathrm{CO}_{2}$ exchange rate measurement. Seasonal precipitation and air temperature were obtained from a weather station near the site.

Soil respiration rate and soil temperature $(2.5 \mathrm{~cm}$ depth) were measured (PP Systems model SRC, Hertfordshire, UK.) on 5 small plots $\left(82 \mathrm{~cm}^{2}\right)$ next to each of the $1 \mathrm{~m}^{2}$ plots at the same time as the $\mathrm{CO}_{2}$ exchange rate measurements. Plastic rings were inserted about $2.5 \mathrm{~cm}$ into the ground and all above-ground vegetation was clipped from within the ring. These small plots rested for 2 weeks before soil respiration rate was measured to avoid $\mathrm{CO}_{2}$ fluctuations associated with soil disturbance. All above-ground vegetation was clipped prior to each measurement. These rings were moved twice during each season. In 1995 the soil respiration measuring equipment was not available until the later part of the season. Therefore, soil respiration rate was only measured on the last 2 sampling dates. The $\mathrm{CO}_{2}$ exchange rate, calculated on a ground surface area basis, was corrected for soil respiration by adding the soil respiration rate (when available) to the chamber $\mathrm{CO}_{2}$ exchange rate. Therefore, $\mathrm{CO}_{2}$ exchange rate comprises plant canopy photosynthesis and respiration only.

Statistical analysis such as analysis of variance are not appropriate for this experiment since we only have 1 true experimental unit per treatment. Data from the five, $1 \mathrm{~m}^{2}$ plots in each pasture are presented here as means + standard errors.

\section{Results}

Spring (May and June) of 1995 had greater than average precipitation, and May temperatures were cooler than long term averages (Fig. 1). Precipitation and temperature were more similar to longterm averages in 1996, while precipitation was higher than normal during the late summer of 1997 . Soil water content varied greatly depending upon the season, but the ungrazed pasture tended to have higher soil water content than either of the grazed pastures (Fig. 2). This was believed to be the result of the greater accumulation of litter and standing dead in the exclosure (Schuman et al. 1999), which acts as a mulch, particularly in the spring time after water has been stored during the winter (Bremer et al. 1998). Although it is not apparent in Figure 1, due to greater than normal early June and late July precipitation, in 1997 a significant drought occurred from mid June to late July (see Fig. 2)

On the first measurement date in 1995 (16 May), $\mathrm{CO}_{2}$ exchange rate was higher in both of the grazed pastures compared to the exclosure (Fig. 3A). Poor weather prevented sampling again for almost 4 weeks. On the next sampling date (13 June) the grazed plots again had higher $\mathrm{CO}_{2}$ exchange rates than the exclosure, although treatment differences were very small. The same trend suggests that there was a period of several weeks when the $\mathrm{CO}_{2}$ exchange rate was higher in the grazed vs. exclosed pastures. In contrast, $\mathrm{CO}_{2}$ exchange rate was typically lower in the grazed pastures in autumn. Seasonal trends in $\mathrm{CO}_{2}$ exchange rate among the grazing strategies were similar to trends in green vegetation index (Fig. 3B). Green vegetation index was higher in the grazed pastures on the first 2 measurement dates and was lower in the grazed pastures later in the season (green vegetation index was not measured on 14 September 1995). On the 2 dates that we measured soil respiration rate, the exclosure had the lowest res-

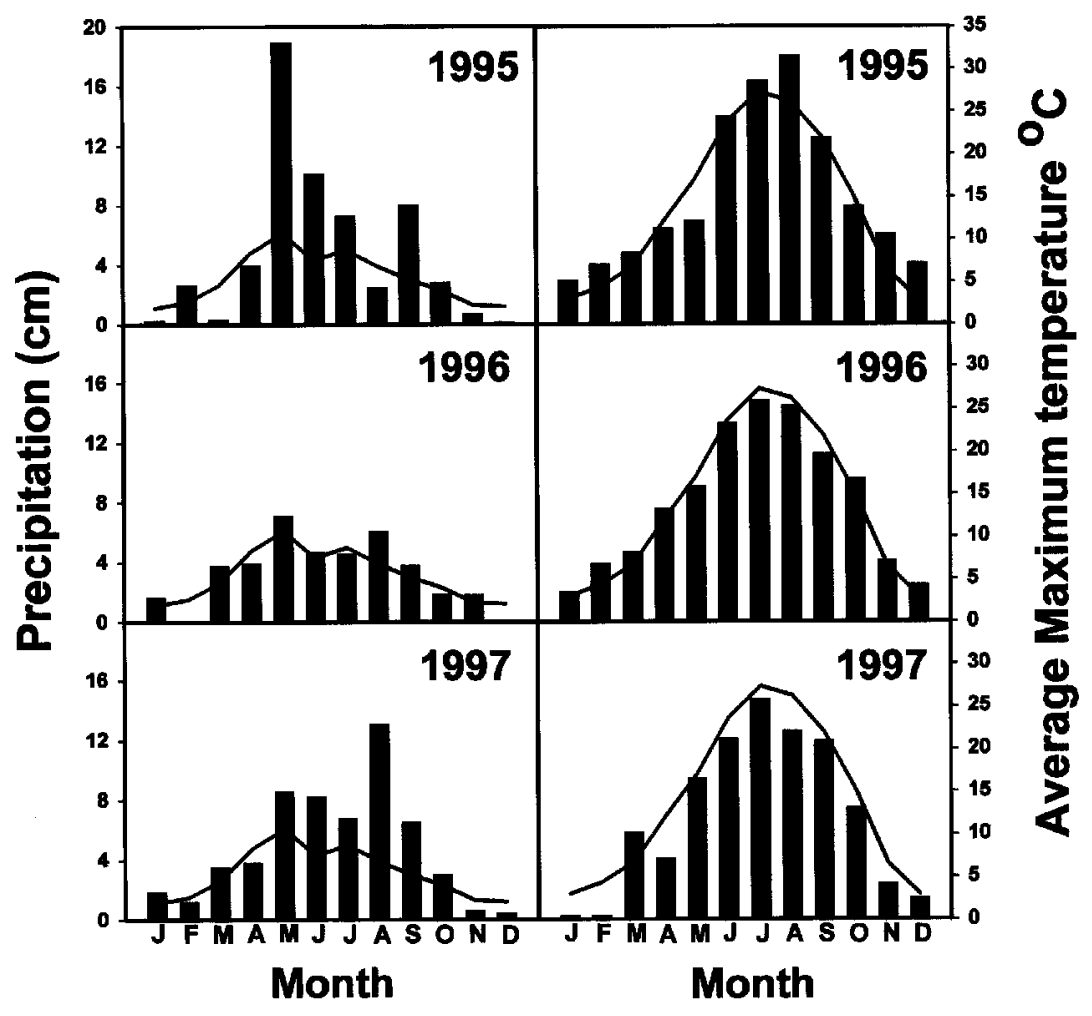

Fig. 1. Monthly total precipitation and average monthly maximum air temperatures of a mixed grass prairie site in Wyoming. The lines are long-term averages. 


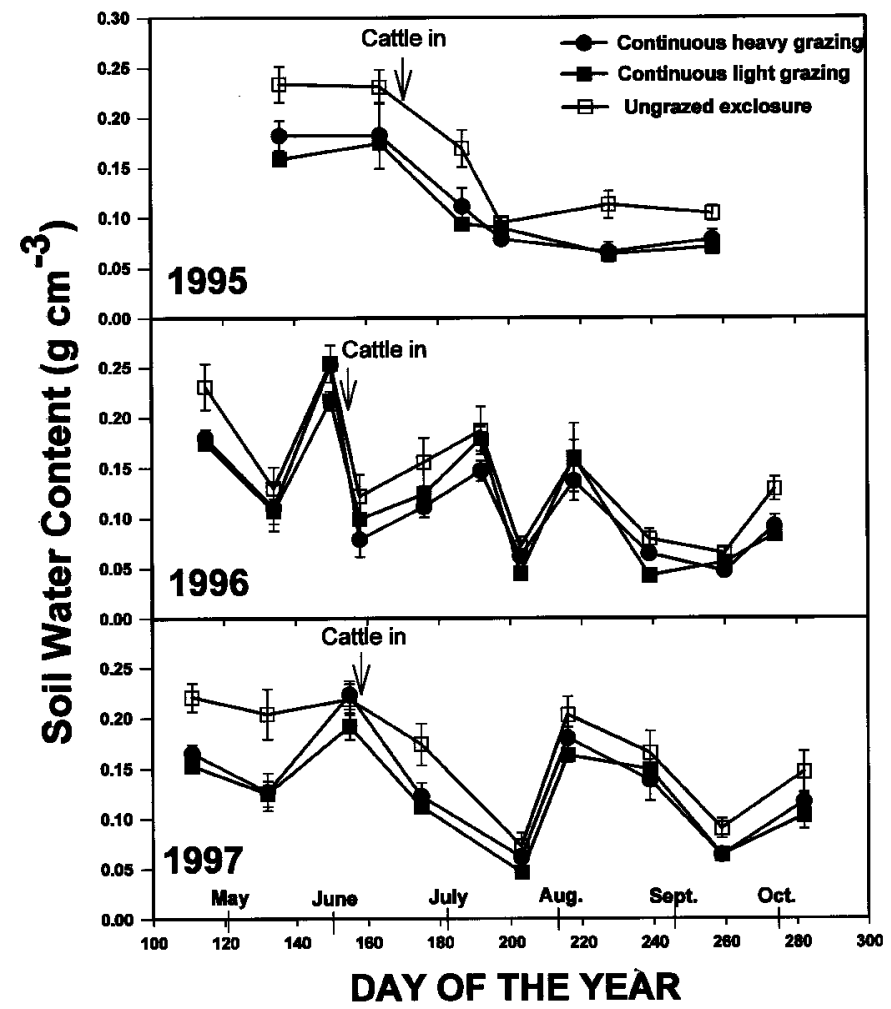

Fig. 2. Soil water content in the upper $30 \mathrm{~cm}$ of 3 mixed grass prairie pastures subjected to different grazing intensities. The $X$ axis has the first day of the month marked. Data are means of 3 replications + standard errors.

piration rate and there was little difference between the heavily and lightly grazed pastures (Fig. 3C).

In 1996 only the heavily grazed pasture had greater $\mathrm{CO}_{2}$ exchange rate than the exclosure on the first measurement date (24 April) (Fig. 4A). This trend continued for the next 2 measurement dates (13 May and 29 May), although differences were small. As in 1995, the heavily grazed pasture also had the greatest green vegetation index early in the season (Fig. 4B). Contrary to 1995 , the $\mathrm{CO}_{2}$ exchange rate and green vegetation index in the lightly grazed pasture were not higher than the exclosure in the spring of 1996. As in 1995 , once cattle were put in the pastures the green vegetation index declined slightly in the continuous heavy compared to the continuous light and exclosed pastures. $\mathrm{CO}_{2}$ exchange rate also tended to be lowest in the heavily grazed pasture during this period. During the spring of 1996 there were 2 measurement dates when soil respiration rate was slightly higher in the continuous heavy pasture than the continuous light and exclosure (day of the year 150 and 158) (Fig. 4C). There was no difference in soil respiration rate among the grazing treatments during the rest of the season.
On the first 4 measurement dates during the spring of 1997 (21 April-24 June) the $\mathrm{CO}_{2}$ exchange rate was higher in both the heavily and lightly grazed pastures compared with the exclosure (Fig. 5A). An ensuing drought caused $\mathrm{CO}_{2}$ exchange rates to drop to near zero in all pastures by mid July. $\mathrm{CO}_{2}$ exchange rates recovered following late July and early August precipitation, but there were no treatment differences for the rest of the season. Higher $\mathrm{CO}_{2}$ exchange rates in the 2 grazed pastures was again accompanied by greater green vegetation index although not on day of the year 155 (Fig. 5B). Surprisingly, green vegetation index was highest in the heavily grazed pasture on 3 dates in July and August (day of the year 203, 216, 239) but this did not result in greater $\mathrm{CO}_{2}$ exchange rate. There were 2 dates during the 1997 season when the continuous heavy pasture had a higher soil respiration rate than the continuous light and exclosed pastures (Fig. 5C). In none of the three years were treatment differences in $\mathrm{CO}_{2}$ exchange rate associated with air or soil temperature at the time of measurement (data not shown).

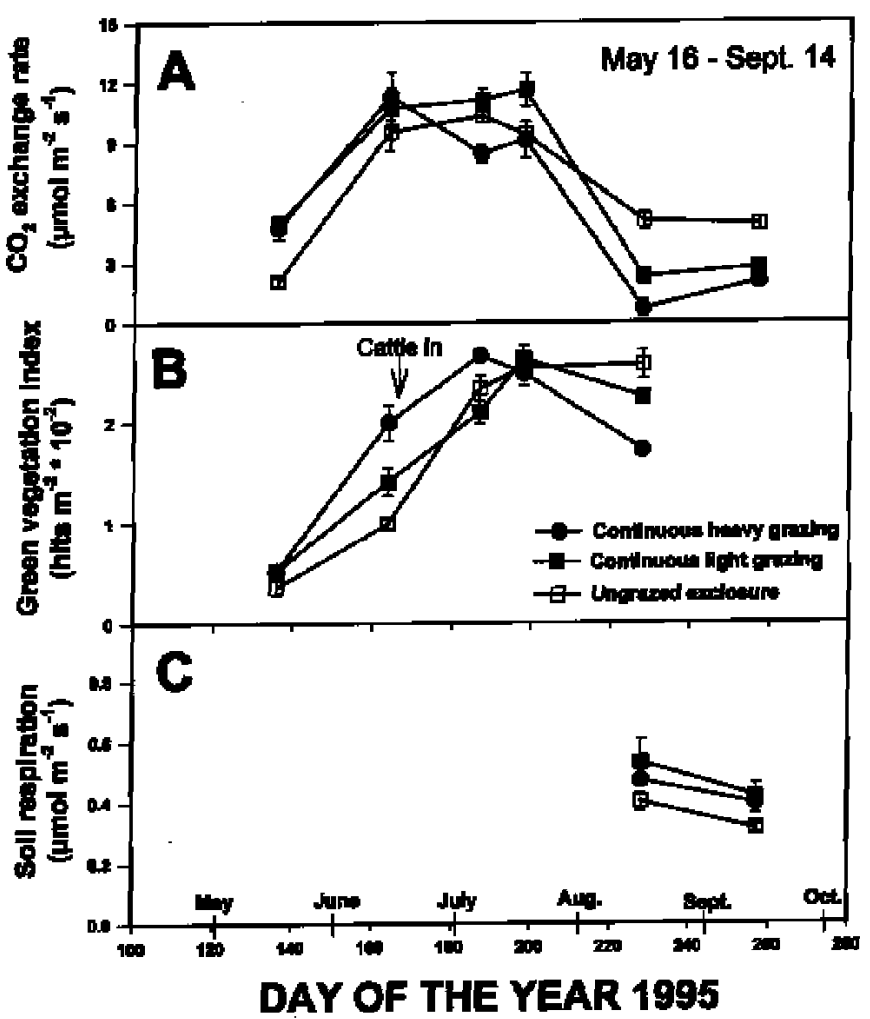

Fig. 3. 1995 data of $\mathrm{CO}_{2}$ exchange rate (corrected for soil respiration when available; $\mathrm{A}$ ), green vegetation index $(B)$ and soil respiration rate $(C)$ of 3 mixed grass prairie pastures subjected to different grazing intensities (the soil respiration equipment was not available until the final 2 dates). The $\mathbf{X}$ axis has the first day of the month marked. Data are means of 5 replications + standard errors. 


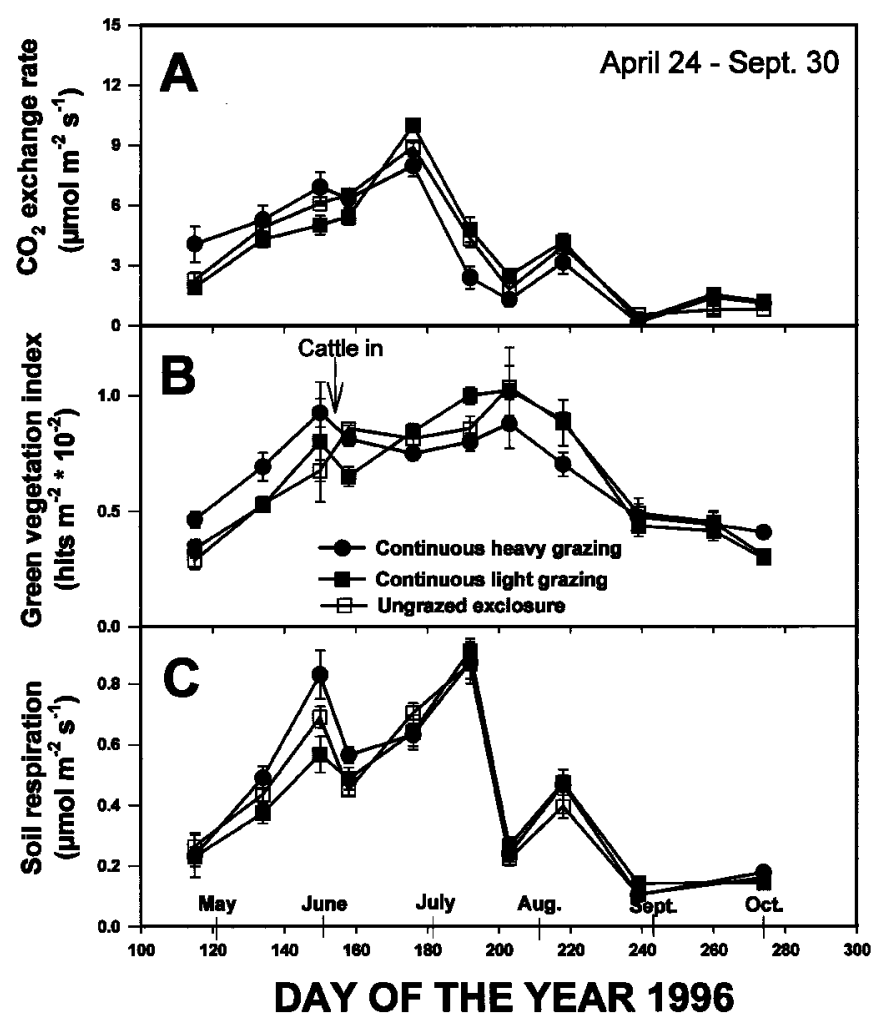

Fig. 4. 1996 data of $\mathrm{CO}_{2}$ exchange rate (corrected for soil respiration; $\mathrm{A}$ ), green vegetation index $(B)$ and soil respiration rate $(C)$ of 3 mixed grass prairie pastures subjected to different grazing intensities. The $X$ axis has the first day of the month marked. Data are means of 5 replications + standard errors.
Our data do not allow us to calculate annual net primary productivity, however, by averaging the $\mathrm{CO}_{2}$ exchange rate data over each season we can look at overall trends in carbon exchange resulting from 13 and more years of grazing. When the data are averaged over the entire season, within each year, they show no difference in the average $\mathrm{CO}_{2}$ exchange rate among these 3 grazing systems, although in 1997 there is a trend for greater $\mathrm{CO}_{2}$ exchange rate in the continuous heavy pasture, compared with exclosure (Table 1). Though the grazed pastures often had higher $\mathrm{CO}_{2}$ exchange rate early in the season, the exclosure often had equal or higher rates during mid to late season.

Since changes in species composition may affect seasonal $\mathrm{CO}_{2}$ exchange rate and soil carbon (Smoliak et al. 1972), the occurrence of the most prevalent species (as detected by the point frame) was averaged over the entire study (Table 2 ). There is relatively more blue grama in the continuous heavy and exclosed pastures than the continuous light pasture. Blue grama $\left(\mathrm{C}_{4}\right)$ appears to be replaced by the $\mathrm{C}_{3}$ species fringed sage (Artemisia frigida Willd.) and scarlet globemallow (Sphaeralcea coccinea (Nutt.) Rydb.) in the continuous light pasture. The continuous heavy pasture has less western wheatgrass than the continuous light and exclosure, but more carex (Carex eleocharis Bailey) plants. Overall, there are only small changes in species composition induced by grazing for 13 plus years. Also, no significant difference in belowground biomass was detected in these pastures (Schuman et al., 1999). Our data differ somewhat from those of Schuman et al. (1999) who measured botanical composition as a percentage of harvested peak standing crop, and found higher amounts of blue grama in the continuous heavy treatment than both the continuous light and exclosure pastures. The differences noted above may be a result of the particular placement of our $1 \mathrm{~m}^{2}$ frames in these large pastures, or that our data are averaged over many dates through the season rather than at peak standing crop.

\section{Discussion}

\section{$\mathrm{CO}_{2}$ exchange rates}

Though there was year to year variation in this study, the seasonal pattern consisted of higher $\mathrm{CO}_{2}$ exchange rates in the grazed plots (most consistently in the con-

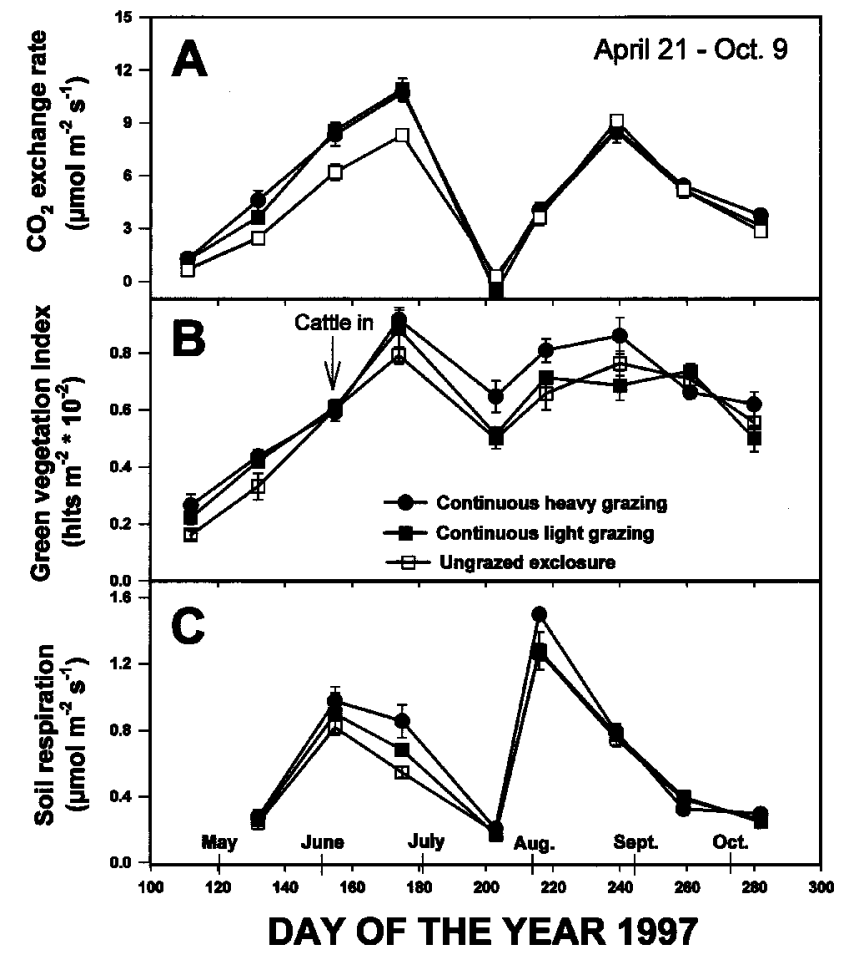

Fig. 5. 1997 data of $\mathrm{CO}_{2}$ exchange rate (corrected for soil respiration; A), green vegetation index $(B)$ and soil respiration rate $(C)$ of 3 mixed grass prairie pastures subjected to different grazing intensities. The $X$ axis has the first day of the month marked. Data are means of 5 replications + standard errors. 
Table 1. The $\mathrm{CO}_{2}$ exchange and soil respiration rates of grazed and ungrazed mixed grass prairie pastures near Cheyenne Wyoming (averaged over the entire growing season) ${ }^{1}$.

\begin{tabular}{|c|c|c|c|c|c|c|}
\hline \multirow[b]{2}{*}{ Treatment } & \multicolumn{3}{|c|}{$\mathrm{CO}_{2}$ exchange rate } & \multicolumn{3}{|c|}{ Soil respiration rate } \\
\hline & 1995 & 1996 & 1997 & 1995 & 1996 & 1997 \\
\hline & $\ldots$ &.- & 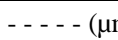 & $\left.\mathrm{n}^{-2} \sec ^{-1}\right)-$ & - - --" - - - & $\ldots \ldots$ \\
\hline Continuous heavy grazing & $6.1 \pm 0.8$ & $3.9 \pm 0.4$ & $5.2 \pm 0.5$ & $0.43 \pm .02$ & $0.47 \pm .04$ & $0.66 \pm .07$ \\
\hline Ungrazed exclosure & $6.9 \pm 0.6$ & $4.0 \pm 0.4$ & $4.3 \pm 0.5$ & $0.43 \pm .04$ & $0.43 \pm . .04$ & $0.56 \pm .06$ \\
\hline
\end{tabular}

${ }^{1}$ Data are means \pm standard errors of 6,11 , and 9 measurement dates for $\mathrm{CO}_{2}$ exchange rate and 2, 10, and 8 dates for soil respiration rate in 1995,1996 , and 1997 , each of 5 replicate plots.

tinuous heavy pasture) compared with the exclosure in the spring (April, May, early June), with differences diminishing by mid June, followed by occasional higher $\mathrm{CO}_{2}$ exchange rate in the ungrazed pasture late in the season. Treatment differences in $\mathrm{CO}_{2}$ exchange rate were associated with differences in green vegetation index, indicating earlier spring green-up in the grazed pastures. There was no apparent correlation between treatment differences in $\mathrm{CO}_{2}$ exchange rate and yearly climate variation.

We did not measure litter and standing dead in this study. However, Schuman et al. (1999), using these same pastures, showed that grazing greatly reduced litter and standing dead, while in the exclosure, $72 \%$ of the above-ground phytomass was litter and standing dead. We hypothesize that earlier spring green-up (measured as higher green vegetation index) and higher $\mathrm{CO}_{2}$ exchange rates in grazed pastures is due to better light penetration and warmer microclimate conditions near the soil surface as a result of less litter and standing dead than in the ungrazed pasture. Our hypothesis is supported by Bremer et al. (1998), who attributed warmer soil temperature in clipped vs. unclipped plots to improved radiation penetration resulting from less litter and standing dead. We were unable to measure canopy light penetration in our system, as it is very difficult to assess accurately where plant canopy structure is low. Summarizing over the 3year period of this study, we conclude that these intensities of grazing do not have a large effect on daytime carbon exchange of the mixed-grass prairie of Wyoming.

\section{Soil respiration rate}

When examined on a seasonal basis, we found no difference in soil respiration rate in grazed vs. ungrazed pastures (Table 1), but there were several dates over the 3 years when soil respiration rate was higher in the grazed vs. ungrazed pastures. These results differ from Bremer et al. (1998) who reported reduced soil respiration in grazed vs. ungrazed tallgrass prairie. In that study the reduction in photosynthetic surface area and available carbohydrates was reported to be the dominating factor in lowered respiration rates. In our ecosystem, photosynthesis was actually higher in the grazed pastures early in the season. Therefore, higher soil respiration rates in the spring may be indicative of greater carbon allocation to roots. Our maximum soil respiration rates were about $10 \%$ of those of the tallgrass prairie, indicating very different soil microbial and root respiration activity between tallgrass and mixed grass prairie ecosystems.

\section{Green vegetation index and species composition}

It was surprising in 1997 not to see a decrease in $\mathrm{CO}_{2}$ exchange rate and green vegetation index in the heavily grazed pasture after cattle were put in the pasture. The introduction of cattle was followed by a severe drought period in 1997 (Fig. 2). Plant responses to drought, rather than grazing treatment, may have been the overriding factor in any treatment differences measured during and following the drought period in 1997.

There was no apparent relationship between the small differences in species composition in these pastures and the seasonal trends in $\mathrm{CO}_{2}$ exchange rate. In a similar study (LeCain et al. 1998), conducted on the shortgrass prairie of eastern Colorado, long-term grazing elicited a shift in species composition to a greater dominance of blue grama. The prevalence of this warm-season grass was related to higher $\mathrm{CO}_{2}$ exchange rate in the grazed pastures when warm temperatures occurred, while the exclosure, with a greater percentage of cool-season species, had higher $\mathrm{CO}_{2}$ exchange rate when weather was cool. No such relationship was seen in the mixed grass prairie study. However, shifts in species composition in these pastures are likely to be more of a factor in the future (Schuman et al. 1999).

\section{Effects of $\mathrm{CO}_{2}$ exchange and soil respiration rates on soil carbon}

Our data show only small differences in $\mathrm{CO}_{2}$ exchange rate and soil respiration rate between grazed and exclosed pastures when the rates are averaged within each year (Table 1), suggesting little effect of grazing on soil carbon concentration in our study. However, our ability to make conclusions about effects of carbon

Table 2. The relative abundance ${ }^{1}$ of major species on grazed and ungrazed mixed grass prairie pastures near Cheyenne Wyo., as determined by the point frame method.

\begin{tabular}{lccc}
\hline \hline & \multicolumn{2}{c}{ Grazing intensity } & Ungrazed \\
\cline { 2 - 3 } Species & Continuous heavy & Continuous light & $36.5 \pm 3$ \\
Blue grama (Bouteoloua gracilis (H.B.K.) Lag. Ex Steud.) & $37.0 \pm 3$ & $25.3 \pm 2$ & $22.8 \pm 2$ \\
Western Wheatgrass (Pascopyrum smithii (Rydb.) A. Love) & $10.5 \pm 1.5$ & $22.9 \pm 2$ & $8.1 \pm 0.9$ \\
Carex (Carex eleocharis Bailey) & $15.0 \pm 1$ & $3.6 \pm 0.6$ & $6.0 \pm 0.8$ \\
Fringed Sage (Artemisia frigida Willd.) & $8.1 \pm 0.5$ & $26.0 \pm 2$ & $5.0 \pm 0.5$ \\
Scarlet globemallow (Sphaeralcea coccinea (Nutt.) Rydb.) & $3.2 \pm 0.3$ & $12.0 \pm 1$ & $6.0 \pm 0.9$ \\
Needle-and-thread grass (Stipa comata Trin and Rupr.) & $3.2 \pm 0.3$ & $2.0 \pm 0.3$ & \\
\hline
\end{tabular}

Relative abundance is the percentage of point frame "hits" over 3 years worth of data on 5 replicate plots (125 measurements) \pm standard error. 
exchange on soil carbon are limited because our measurements were performed at 3 week intervals through the season and only during periods of maximum daily photosynthesis. We do not know the proportion of spring days during which grazed plots had higher $\mathrm{CO}_{2}$ exchange rates, nor how many days during the summer that $\mathrm{CO}_{2}$ exchange rate was lower in the continuous heavy plots, nor if treatment differences seen at midday occur diurnally.

The influence of observed seasonal trends in $\mathrm{CO}_{2}$ exchange rate on soil carbon depends on interactive effects of grazing and rainfall on $\mathrm{CO}_{2}$ exchange rate and seasonal patterns of partitioning of photosynthate between above and below-ground organs. On the northern mixed grass prairie most of the above-ground production typically occurs prior to July when soil moisture and temperature are favorable for growth of the dominant $\mathrm{C}_{3}$ species (Sims and Singh 1978a, also see green vegetation index in Figs. 3, 4, and $5)$. Although a direct effect of grazing is to decrease carbon allocation to the roots during above-ground regrowth (Caldwell et al. 1981, Detling et al. 1979) much of the period of higher $\mathrm{CO}_{2}$ exchange rate which we measured in grazed pastures occurred before cattle were introduced. Higher $\mathrm{CO}_{2}$ exchange rate and productivity in grazed vs. ungrazed pastures during this part of the season are likely accompanied by greater carbon allocation to the roots. Over time this could increase soil carbon concentration. There was also a trend for greater soil respiration in the grazed compared to the ungrazed pastures early in the season, particularly in the heavily grazed pasture. This is another indication of improved biological activity and greater carbon allocation to roots during the early part of the season in grazed pastures, probably because of warmer soil temperature (Bremer et al. 1998).

In typical years, soils dry out as the season progresses and $\mathrm{CO}_{2}$ exchange rate and plant productivity slows. The $\mathrm{CO}_{2}$ exchange rate declines as defoliation by grazers lowers the photosynthetic surface area. This suggests less below-ground carbon allocation in grazed vs. ungrazed pastures during the later part of the season. However, much of the mid- to late-season photosynthate in range grasses is used in storage, rather than shoot or root growth, as plants prepare for summer or winter dormancy (White 1973). Most late season carbohydrates are stored in the stem bases and crowns and are utilized in winter respiration and leaf tissue regeneration in early spring (White 1973). Therefore, these carbon compounds may have less effect on soil carbon concentration than carbon used for structural root growth early in the season (Dormaar and Sauerbeck 1983). Further studies are necessary to determine precisely how seasonal differences in $\mathrm{CO}_{2}$ exchange rate and soil respiration influence soil carbon in this ecosystem.

\section{Conclusion}

Our expectation that seasonal $\mathrm{CO}_{2}$ exchange rate would be associated with the amount of green vegetation in the pastures was largely confirmed in this study. However, the discovery of higher $\mathrm{CO}_{2}$ exchange rate and earlier spring green-up in grazed pastures was unanticipated, and perhaps the most interesting find. Overall, our data show that cattle grazing, at the intensities used in this study, elicits only small changes in ecosystem carbon exchange, soil respiration rate, green vegetation production and species composition. These results agree with studies conducted on the nearby shortgrass prairie, where the ecosystem has been found to be very tolerant of cattle grazing. Semiarid grasslands with a long history of grazing respond to grazing with only small changes in annual net primary productivity and community composition (Milchunas et al. 1988, Milchunas and Lauenroth 1993). In both systems up to $90 \%$ of the plant based carbon is below-ground (Schuman et al. 1999, Milchunas et al. 1998). Therefore, removal of even $50 \%$ of the above-ground plant material (as in the continuous heavy treatment) has only a small effect on ecosystem functioning.

\section{Literature Cited}

Angell, R. and T. Svejcar. 1999. A chamber design for measuring net $\mathrm{CO}_{2}$ exchange on rangeland. J. Range Manage. 52:27-31.

Bauer, A., C.V. Cole and A.L. Black. 1987. Soil property comparisons in virgin grasslands between grazed and nongrazed management systems. Soil Sci. Soc. Amer. J. 51:176-182.

Berg, W.A., J.A. Bradford, and P.L. Sims. 1997. Long-term soil nitrogen and vegetation change on sandhill rangeland. J. Range Manage. 50:482-486.

Bremer, D.J., J.M. Ham, C.E. Owensby and A.K. Knapp. 1998. Responses of soil respiration to clipping and grazing in a tallgrass prairie. J. Environ. Qual. 27:1539-1548.
Caldwell, M.M., J.H. Richards, D.A. Johnson, R.S. Nowak, and R.S. Dzurec. 1981. Coping with herbivory: Photosynthetic capacity and resource allocation in two semiarid Agropyron bunchgrasses. Oecologia 50:14-24.

Detling, J.K., M.I. Dyer, and D.T. Winn. 1979. Net photosynthesis, root respiration and regrowth of Bouteloua gracilis following simulated grazing. Oecologia 41:127-134.

Detling, J.K., W.J. Parton, and H.W. Hunt. 1978. An empirical model for estimating $\mathrm{CO} 2$ exchange of Bouteloua gracilis (H.B.K.) Lag. in the shortgrass prairie. Oecologia 33:137-147.

Dormaar, J.F. and D.R. Sauerbeck. 1983. Seasonal effects on photoassimilated carbon14 in the root system of blue grama and associated soil organic matter. Soil Biol. Biochem. 15:475-479.

Dormaar, J.F. and W.D. Willms. 1998. Effect of forty years of grazing on fescue grassland soils. J. Range Manage. 51:122-126.

Hart, R.H., M.J. Samuel, P.S. Test, and M.A. Smith. 1988. Cattle, vegetation and economic responses to grazing systems and grazing pressure. J. Range Manage. 41:282-286.

Hazlett, D.L. 1992. Leaf area development of four plant communities in the Colorado steppe. Amer. Midl. Nat. 127:276-289.

LeCain, D.R., J.A. Morgan, G.E. Schuman, J.D. Reeder, and R.H. Hart. 1998. Cattle grazing and carbon assimilation in the shortgrass steppe of eastern Colorado. American Society of Agronomy abstracts. Baltimore, Md. October, 1998.

Manley, J.T., G.E. Schuman, J.D. Reeder and R.H. Hart. 1995. Rangeland soil carbon and nitrogen responses to grazing. J. Soil and Water Cons. 50:294-298.

McNaughton, S.J. 1979. Grazing as an optimization process: Grass-ungulate relationships in the serengeti. The American Naturalist. 113:691-703.

MeNaugton, S.J., D.G. Milchunas, and D.A. Frank. 1996. How can net primary productivity be measured in grazing ecosystems? Ecology 77:974-977.

Milchunas, D.G. and W.K. Lauenroth. 1993. Quantitative effects of grazing on vegetation and soils over a global range of environments. Ecol. Mono. 63:327-366.

Milchunas, D.G., W.K. Lauenroth and I.C. Burke. 1998. Livestock grazing: animal and plant biodiversity of shortgrass steppe and the relationship to ecosystem functioning. Oikos 83:65-74.

Milchunas, D.G., O.E. Sala, and W.K. Lauenroth. 1988. A generalized model of the effects of grazing by large herbivores on grassland community structure. The Amer. Naturalist 132:87-106.

Morgan, J.A. and R.H. Brown. 1983. Photosynthesis and growth of Bermudagrass swards. II. Growth patterns as estimated by harvest and gas exchange techniques. Crop Sci. 23:352-357.

Painter, E.L. and J.K. Detling. 1981. Effects of defoliation on net photosynthesis and regrowth of western wheatgrass. J. Range Manage. 34:68-71. 
Ruess, R.W. and S.J. McNaughton. 1987. Grazing and the dynamics of nutrient and energy regulated microbial processes in the Serengeti grasslands. Oikos 49:101-110.

Schuman, G.E., J.D. Reeder, J.T. Manley, R.H. Hart, and W.A. Manley. 1999. Impact of grazing management on the carbon and nitrogen balance of a mixed-grass prairie. Ecol. Appl. 9:65-71.

Shaw, J.H. 1995. How many bison originally populated western rangelands? Rangelands 17:148-150.
Sims, P.L. and J.S. Singh. 1978a. The structure and function of ten western North American grasslands II. Intra-seasonal dynamics in primary producer compartment. J. Ecol. 66:547-572.

Sims, P.L. and J.S. Singh. 1978b. The structure and function of ten western North American grasslands III. Net primary production, turnover and efficiencies of energy capture and water use. J. Ecol. 66:573-597.

Smoliak, S., J.F. Dormaar, and A. Johnston. 1972. Long-term grazing effects on Stipa-Bouteloua prairie soils. J. Range Manage. 25:246-250.
Stebbins, G.L. 1981. Coevolution of grasses and herbivores. Ann. Missouri Bot. Gard. 68:75-86.

Wallace, L.L. 1990. Comparative photosynthetic responses of big bluestem clipping versus grazing. J. Range Manage. 43:58-61.

Warren-Wilson, J. 1963. Estimation of foliage denseness and foliage angle by inclined point quadrats. Aust. J. Bot. 11:95-105.

White, L.M. 1973. Carbohydrate reserves in grasses: a review. J. Range Manage. 26:13-18. 